\title{
THEORETICAL ANALYSIS OF TUNNEL LINING SUBJECTED TO FIRE
}

\author{
M. H. Mansour \\ Civil Engineering Department, Faculty of Engineering, Assiut \\ University, Assiut, Egypt.mhm_Soliman@yahoo.com
}

(Received January 26, 2010 Accepted March 1, 2010).

\begin{abstract}
The present paper aims to investigate the impact of fire on the behavior of concrete structures such as tunnels. In this paper, the non-uniform work hardening plasticity model (Willam-Warnke five-parameter model) was adopted as yield and failure criteria for concrete. The tunnel was investigated after being exposed to a fire, by means of a FE 3-D model. Moreover, the behavior of the tunnel during heating and cooling processes was studied. Furthermore, the tunnel was also analyzed by a FE 2-D model, in order to make comparisons between the two models.
\end{abstract}

KEYWORDS: William-Warnke; 3-D Analysis; Tunnel Lining; Fire loading

\section{1- INTRODUCTION}

In recent years many accidents have dramatically and clearly underlined the catastrophic impact that may be caused by tunnel fires. The risk of tunnel fires increases accordingly as traffic volumes rise and in turn, as the number of tunnels continues to grow.

Tunnel lining usually made from concrete or shotcrete that can explosively spall during a fire with high heat release rates and temperatures [1]. For many years, structural fire design for general concrete members and structures focused mainly on buildings $[1,2,3,4]$. The effect of fire impact on tunnels can be more severely than its effect on building. Due to its economic and politic impact, the question's answer of whether and when a tunnel is reactivated for traffic after a fire is very critical issue.

In tunnel engineering, it is necessary to analyze and check the structure with a soil-tunnel model under high temperature. In this paper, the severe impact of fire is represented by the increase of stresses due to high temperature and the decrease of the load bearing capacity of the concrete lining due to the mechanical and chemical changes in the materials during heating and cooling processes. The fire is assumed to occur inside the tunnel and induced damage to be localized in the upper part of the lining. The behavior of the structure was studied at different times after fire occurrence. Eventually, a cooling process was applied and the behavior of the tunnel was investigated, as well. The analysis is related to continuous shotcrete (and in-situ) tunnel linings.

\section{MODELING OF THE THERMAL FIELD}

The temperature distribution over the depth of any concrete member can be calculated using a numerical procedure. This can be done using the analytical solution for one- 
dimensional heat conduction accounting for heat absorption due to evaporation phase change for the free water and the water of hydration in the concrete. This solution however does not account for temperature dependency of the thermal properties in concrete and other nonlinearities. For tunnel lining, Eurocode-2 [5] parametric fire was used to calculate the temperature profile through the tunnel thickness. The temperature distribution through concrete was calculated by laboratory tests by exposing concrete specimens to high temperature and measuring the temperature at different distances through the specimen. Fig. (1) shows the variation of temperature over the thickness of the concrete specimens at various times during heating and cooling phases. These curves and similar curves are used by a lot of investigators for tunnel calculations [6]. The curves for times 30,60 and 120 minutes describe the heating phase and the curves for times 180 and 240 minutes represent the cooling phase.

After defining the temperature distribution through the lining thickness, the thermal stresses and strains can be calculated at any point, by the FINAL program [7].

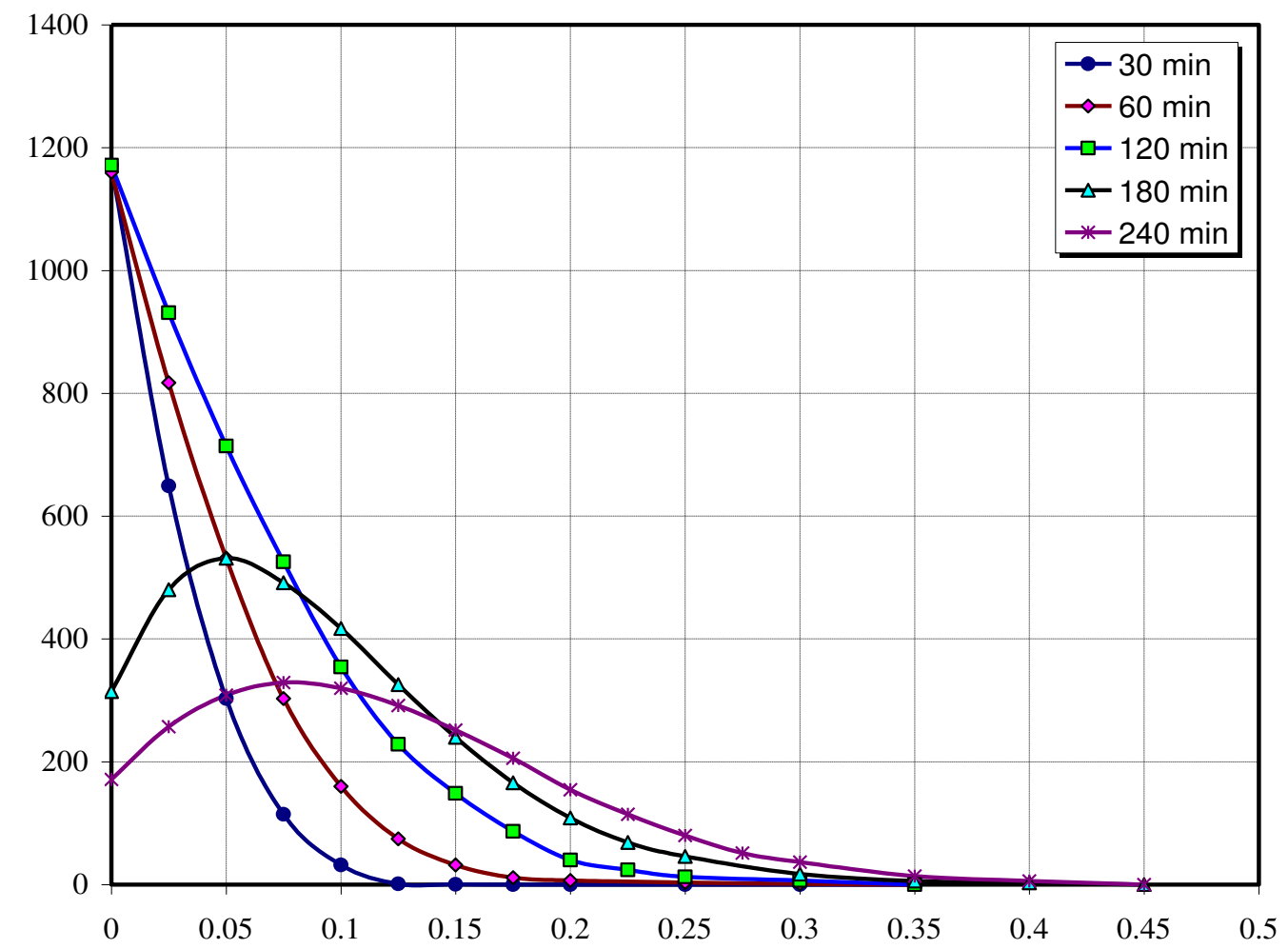

Distance from heated face

Fig. (1): Temperature distribution in concrete (heating and cooling) [3]

\section{THEORETICAL PLASTICITY MODEL}

This work, which is a development of Han and Chen work hardening plasticity model [8], attempts to develop a relatively comprehensive and sophisticated plasticity model at elevated temperature such that this important features of inelastic deformational 
behavior of concrete as well as of shotcrete, including brittle cracking in tension, work hardening and quasi-ductile behavior in compression, hydrostatic pressure sensitivities, nonlinear volume dilatancy. This model is illustrated in hydrostatic plan by Fig. (2). The failure surface encloses all the loading surfaces and serves as a bounding surface, which is assumed unchanged during loading. The cross sectional shapes of the loading surface on the deviatoric plane are assumed to be similar to that of the failure surface, but their meridians are different. During work hardening, the loading surface expands and changes its shape from its initial shape that matches with initial yield surface to its final shape that matches the failure surface. Each loading surface is characterized by a hardening parameter $k_{0}$, which is a function of the plastic work $[8,9,10,11,12]$.

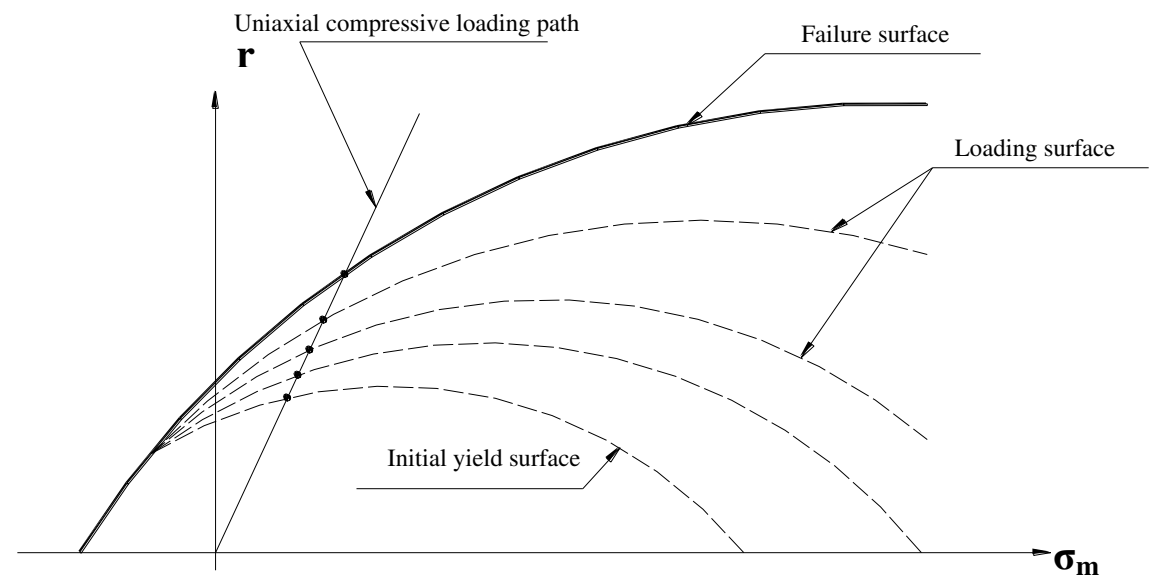

Fig. (2): A non-uniform hardening plasticity model

In this paper, the most sophisticated five-parameter model of William-Warnke was adopted as a yield and failure criteria for concrete. The important feature of this model, as shown in Fig.(3), is that it has curved meridians and bulged triangular shape of deviatoric sections which match exceedingly well the experimental data. This refined model reproduces almost all the important features of tri-axial failure surface for concrete material, gives a close estimation to the relevant experimental data.

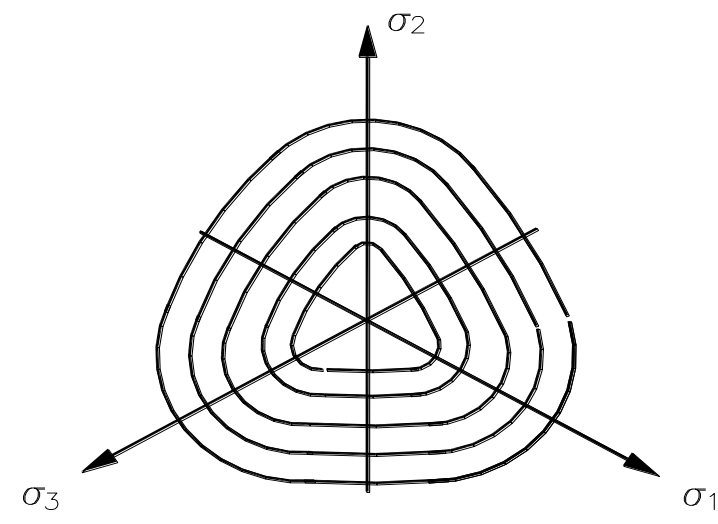

Fig. (3): Failure surface on the deviatoric plane 
The general form of the failure surface for the proposed model can be expressed as:

$$
r-r_{f}\left(\sigma_{m}, \theta\right)=0
$$

This model has curved tensile and compressive meridians expressed by quadratic parabola with the following form:

$$
\begin{array}{ll}
\sigma_{m}=a_{0}+a_{1} r_{t}+a_{2} r_{t}^{2} & \text { (tensile) } \\
\sigma_{m}=b_{0}+b_{1} r_{c}+b_{2} r_{c}^{2} & \text { (compressive) }
\end{array}
$$

Where $r_{t}$ and $r_{c}$ are the stress components perpendicular to the hydrostatic axis at $\theta=0^{\circ}$ and $\theta=60^{\circ}$ respectively. And $a_{0}, a_{1}, a_{2}, b_{0}, b_{1}$ and $b_{2}$ are the material constants with considering $a_{0}=b_{0}$. The remaining five parameters can be determined by five typical experimental tests (uniaxial compressive strength, uniaxial tensile strength, biaxial compressive strength and two confining biaxial compressive strengths). The failure surface of this model can be determined as:

$$
r\left(\sigma_{m}, \theta\right)=\frac{2 r_{c}\left(r_{c}^{2}-r_{t}^{2}\right) \cos \theta+r_{c}\left(2 r_{t}-r_{c}\right)\left[4\left(r_{c}^{2}-r_{t}^{2}\right) \cos ^{2} \theta+5 r_{t}^{2}-4 r_{t} r_{c}\right]^{\frac{1}{2}}}{4\left(r_{c}^{2}-r_{t}^{2}\right) \cos ^{2} \theta+\left(r_{c}-2 r_{t}\right)^{2}}
$$

From Eqns. (2) and (3), $r_{t}$ and $r_{c}$ can be expressed, as:

$$
\begin{aligned}
& r_{t}=-\frac{1}{2 a_{2}}\left[a_{1}+\sqrt{a_{1}^{2}-4 a_{2}\left(a_{0}-\sigma_{m}\right)}\right] \\
& r_{c}=-\frac{1}{2 b_{2}}\left[b_{1}+\sqrt{b_{1}^{2}-4 b_{2}\left(b_{0}-\sigma_{m}\right)}\right]
\end{aligned}
$$

In Eqns. (1) to (4), all stresses and stress invariants have been normalized by $f_{c}^{\prime}$, the uniaxial compressive strength of concrete. The failure function for this family of criteria can be written as:

$$
r-r_{f}=0
$$

The initial and subsequent loading surface can be expressed as:

$$
r-k r_{f}=0
$$

Where $k$ is a shape factor, which is a function of the mean stress $\sigma_{\mathrm{m}}$ and the hardening parameter. The hardening level is defined by the hardening parameter $k_{o}$ while the shape is described by the shape function $\mathrm{k}\left(\sigma_{\mathrm{m}}\right)$. The hardening parameter $\mathrm{k}_{\mathrm{o}}$ takes the value of $\mathrm{k}_{\mathrm{y}} \leq \mathrm{k}_{\mathrm{o}} \leq 1.0$. In the current work, the kinematic-hardening rule of Ziegler, [13], was implemented as a hardening rule and non-associated flow rule were used in this study.

When the plastic flow takes place, and after the mathematical calculations, the final equations can be written as follows:

$$
d \sigma_{i j}=\left(C_{i j k l}^{e}+C_{i j k l}^{p}\right) d \varepsilon_{k l}
$$

Where the plastic stiffness tensor has the form: 


$$
C_{i j k l}^{p}=-\frac{1}{h} H_{i j}^{*} H_{i j}
$$

In which:

$$
H_{i j}^{*}=C_{i j m n}^{e} \frac{\partial g}{\partial \sigma_{m n}}, \quad H_{i j}=\frac{\partial f}{\partial \sigma_{p q}} C_{p q k l}^{e}
$$

where:

$$
h=\frac{\partial f}{\partial \sigma_{m n}} C_{m n p q}^{e} \frac{\partial g}{\partial \sigma_{p q}}+\left[C(1-m) \frac{\partial f}{\partial \sigma_{i j}} \bar{\sigma}_{i j}-H^{p} m \frac{\partial f}{\partial \tau}\right] \phi
$$

and,

$$
\phi=(1 / \tau)\left(\partial g / \partial \sigma_{i j}\right) \sigma_{i j}
$$

Plastic model for steel

The Von Mises criterion was selected as a yield and failure criterion for steel. In this model, it was assumed that yielding occurs when $J_{2}$ reaches a critical value, or:

$$
J_{2}=k
$$

In which $k$ is a material parameter and it can be taken as the yield strength of the steel. Fig. (4) shows the Von-Mises yield surface in the principle stress space and on the $\pi$ plane.

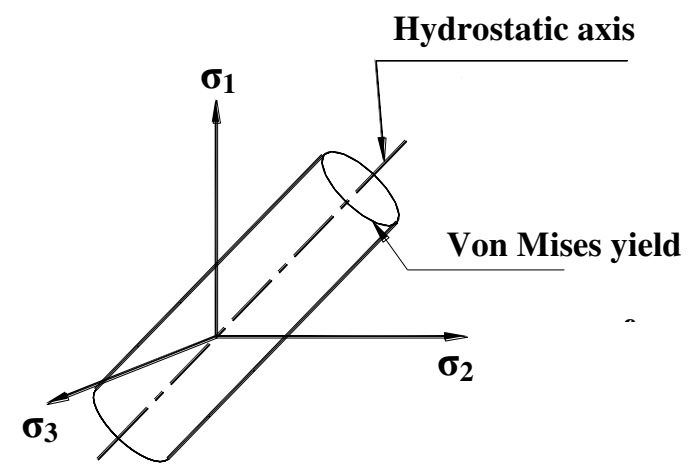

a- In the principle stress space

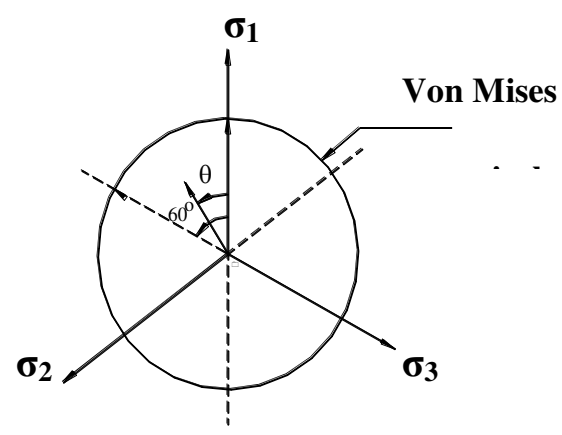

b- On the deviatoric plane

Fig. (4): Von Mises criterion

\section{BRENNER RAILWAY TUNNEL}

Brenner Railway System, Tunnel Baum Kirchen, H7-1 was chosen as an application for two and three-dimensional model of soil-tunnel interaction. The cross section of the tunnel is presented in Fig. (5). The tunnel consists of two linings: An outside shotcrete lining, which carry the soil pressure and inner lining of thickness $55 \mathrm{~cm}$, which carry the water protection membrane. For fire calculation, only the inner lining which represents the support for fire loading has to be considered, this can be done by taking 
a small soil ring around the tunnel. In the analysis, only the upper part of the tunnel was allowed to be influenced by the fire while the lower part had no temperature changes, as shown in Fig. (6).

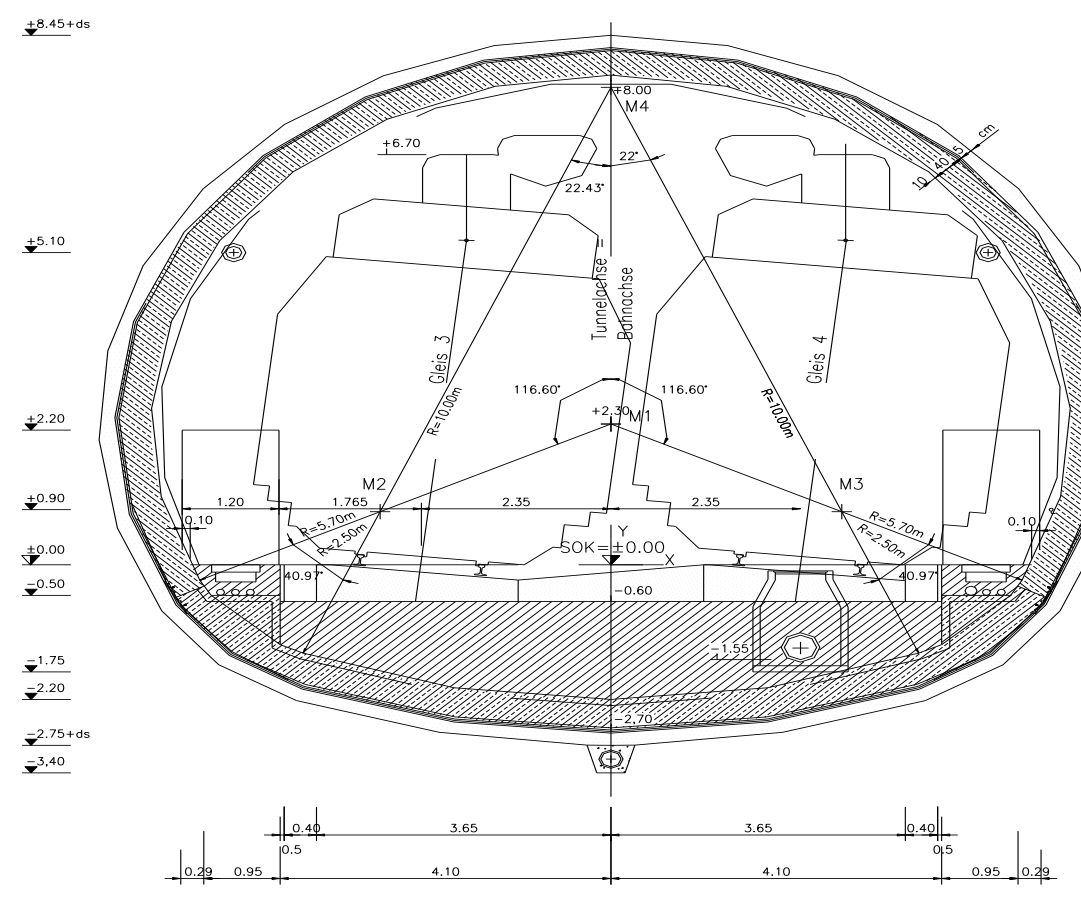

Fig. (5): Cross section in the tunnel

(km 28.890.00 - km 29.002.50)

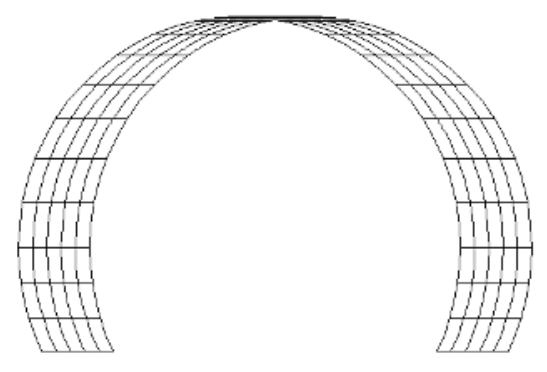

Fig. (6): The upper part of the tunnel which subjected to fire above level $(+0.00)$

\subsection{Materials}

The Soil parameters used in the current investigation were as listed in Table (1). The concrete parameters include the uniaxial compressive strength $f_{c u}=32 \mathrm{MPa}$, the modulus of elasticity $E=3.05 \mathrm{GPa}$, Poisson's ratio $v=0.2$ and the yield stress $=0.35$ 
$f_{c u}$. The reinforcements are of grade $36\left(f_{y}=360 \mathrm{MPa}\right)$, the modulus of elasticity $E=$ $200.0 \mathrm{GPa}$, Poisson's ratio $v=0.3$.

Through the numerical investigation the concrete lining has been divided into various layers with the material properties, as listed in Table (2). The relation between concrete temperature $\mathrm{T}$ and the modulus of elasticity $\mathrm{E}_{0}$ can be defined in CEB [14] curves by two regions as follows:

$$
\begin{aligned}
& E_{T}=E_{0} \quad 0^{\circ} \mathrm{C} \leq \mathrm{T} \leq 70^{\circ} \mathrm{C} \\
& E_{T}=\left[\frac{770-T}{700}\right] E_{0} \quad 70^{\circ} \mathrm{C}<T \leq 700^{\circ} \mathrm{C}
\end{aligned}
$$

\begin{tabular}{|c|c|c|c|c|}
\hline \multicolumn{5}{|c|}{ Soil parameters } \\
\hline$\gamma_{\text {soil }}$ & $E_{\text {soil }}$ & $C_{\text {soil }}$ & $\phi_{\text {soil }}$ & $v_{\text {soil }}$ \\
\hline 25.0 & $20 \times 10^{4}$ & 100 & $35^{\circ}$ & 0.35 \\
\hline $\mathrm{kN/ \textrm {m } ^ { 3 }}$ & $\mathrm{kNN/ \textrm {m } ^ { 2 }}$ & $\overline{k N / m^{2}}$ & - & - \\
\hline
\end{tabular}

Table (1): Material parameters of the soil

Where $\gamma_{\text {soil }}, E_{\text {soil }}, C_{\text {soil }}, \phi_{\text {soil }}, v_{\text {soil }}$ are the density, young's modulus, un-drained cohesion, angle of internal friction and Poisson ratio of the soil respectively.

Table (2): Material parameters and temperatures of the concrete layers at initial state

\begin{tabular}{||c||c||c||c||c||c||}
\hline $\begin{array}{c}\text { Layer } \\
\text { Number }\end{array}$ & $\begin{array}{c}\text { Material } \\
\text { Type }\end{array}$ & $\begin{array}{c}\text { Temperature } \\
{\left[{ }^{\circ} \mathrm{C}\right]}\end{array}$ & $\begin{array}{c}\text { E- modulus } \\
\text { GPa }\end{array}$ & $\begin{array}{c}\text { Poisson } \\
\text { ratio v }\end{array}$ & $\begin{array}{c}\text { Layer } \\
\text { thickness cm }\end{array}$ \\
\hline \hline $1,2,3$ & Concrete & 0 & 30.5 & 0.2 & 2.5 \\
\hline 4 & Steel & 0 & 200 & 0.3 & 0.39 \\
\hline 5 & Concrete & 0 & 30.5 & 0.2 & 2.11 \\
\hline \multirow{nnnnyy}{*}{5 to 18} & Concrete & 0 & 30.5 & 0.2 & 2.5 \\
\hline 19 & Concrete & 0 & 30.5 & 0.2 & 2.4 \\
\hline 20 & Steel & 0 & 200 & 0.3 & 0.10 \\
\hline 21,22 & Concrete & 0 & 30.5 & 0.2 & 2.5 \\
\hline
\end{tabular}

During heating process, the temperature for each layer as well as the modulus of elasticity was calculated. The material parameters at initial state and during heating process were calculated and stated in Tables (2) to (4).

\subsection{Loading Sequence}

As mentioned before, only the upper part of the tunnel was exposed to high temperatures according to Fig. (1) for a period of 120 minute during heating process after that a cooling process took place for another 120 minutes. In the current application, the calculations were made after 60 and 120 minutes for heating process, 
and after another 120 minutes for cooling process. Therefore, the computations were made through four cases of loading, as follows:

Loading case 1: At time 0 , the loadings were the initial stresses that emerged from the own weight of the tunnel lining, the pore water pressure.

Loading case 2: In addition to the initial loadings, a temperature loading after 60 minutes was investigated.

Loading case 3: The temperature loading after 120 minutes,

Loading case 4: Finally, a reduction in the temperature by cooling after 240 minutes was taken into consideration.

Table (3): Material properties and temperatures distribution of the layers after fire

\begin{tabular}{|c|c|c|c|c|}
\hline \multirow{2}{*}{$\begin{array}{l}\text { Layer } \\
\text { Number }\end{array}$} & \multicolumn{2}{|c|}{60 min temperature } & \multicolumn{2}{|c|}{120 min temperature } \\
\hline & $\begin{array}{c}\text { Temperature } \\
{\left[{ }^{\circ} \mathrm{C}\right]}\end{array}$ & $\begin{array}{l}\text { E- modulus } \\
\text { GPa }\end{array}$ & $\begin{array}{c}\text { Temperature } \\
{\left[{ }^{\circ} \mathrm{C}\right]}\end{array}$ & $\begin{array}{l}\text { E- modulus } \\
\text { GPa }\end{array}$ \\
\hline 1 & 989 & 0.0001 & 1052 & 0.0001 \\
\hline 2 & 674 & 41.4 & 823 & 0.0001 \\
\hline 3 & 417 & 15.45 & 620 & 6.5 \\
\hline 4 & 232 & 160 & 441 & 98 \\
\hline 5 & 232 & 23.61 & 441 & 14.4 \\
\hline 6 & 117 & 28.65 & 292 & 20.97 \\
\hline 7 & 53 & 30.5 & 189 & 25.48 \\
\hline 8 & 22 & 30.5 & 119 & 28.61 \\
\hline 9 & 9 & 30.5 & 64 & 30.5 \\
\hline 10 & 5 & 30.5 & 32 & 30.5 \\
\hline 11 & 3 & 30.5 & 19 & 30.5 \\
\hline 12 & 2 & 30.5 & 12 & 30.5 \\
\hline 13 & 1 & 30.5 & 9 & 30.5 \\
\hline 14 & 0 & 30.5 & 5 & 30.5 \\
\hline 15 to 18 & 0 & 30.5 & 0 & 30.5 \\
\hline 19 & 0 & 30.5 & 0 & 30.5 \\
\hline 20 & 0 & 200 & 0 & 200 \\
\hline 21,22 & 0 & 30.5 & 0 & 30.5 \\
\hline
\end{tabular}


Table (4): Material properties after 240 minutes (Cooling)

\begin{tabular}{|c|c|c|}
\hline \multirow[b]{2}{*}{ Layer Number } & \multicolumn{2}{|c|}{240 min temperature } \\
\hline & $\begin{array}{c}\text { Temperature } \\
{\left[{ }^{\circ} \mathrm{C}\right]}\end{array}$ & $\begin{array}{l}\text { E- modulus } \\
\text { GPa }\end{array}$ \\
\hline 1 & 215 & 0.0001 \\
\hline 2 & 283 & 0.0001 \\
\hline 3 & 319 & 6.5 \\
\hline 4 & 325 & 98 \\
\hline 5 & 325 & 13.82 \\
\hline 6 & 306 & 17.45 \\
\hline 7 & 271 & 20.97 \\
\hline 8 & 230 & 21.35 \\
\hline 9 & 181 & 23.75 \\
\hline 10 & 134 & 25.88 \\
\hline 11 & 98 & 27.9 \\
\hline 12 & 64 & 29.53 \\
\hline 13 & 44 & 30.5 \\
\hline 14 & 33 & 30.5 \\
\hline 15 & 20 & 30.5 \\
\hline 16 & 12 & 30.5 \\
\hline 17 & 8 & 30.5 \\
\hline 18 & 5 & 30.5 \\
\hline 19 & 2 & 30.5 \\
\hline 20 & 0 & 200 \\
\hline 21,22 & 0 & 30.5 \\
\hline
\end{tabular}

\section{THREE-DIMENSIONAL MODEL}

In studying tunneling subjected to fire, three-dimensional approach is more appropriate to determine the stresses and the deformations of the soil and the lining realistically [15]. Therefore, a three-dimensional analysis for the tunnel by FINAL program [7], is made in which an Isoparametric Quadratic Solid element (IPQS) is used to model the soil. An Isoparametric Sandwich Shell element with Quadratic shape function (ISSQ) is used to simulate the shotcrete lining. Its multilayer system permits a very good simulation to shotcrete application. The important of this element is that it allows different material properties, an appropriate integration through the thickness of the element and a reasonable number of points where the constitutive laws are satisfied, as shown in Fig. (7). Willam-Warnke criterion [16] was used to define the constitutive law of the shotcrete lining in elastic, work-hardening stages. The finite element meshes used to simulate the soil and tunnel lining are shown in Fig. (8). The results for both surrounding soil and concrete lining are plotted in Figs. (9) to (21). 


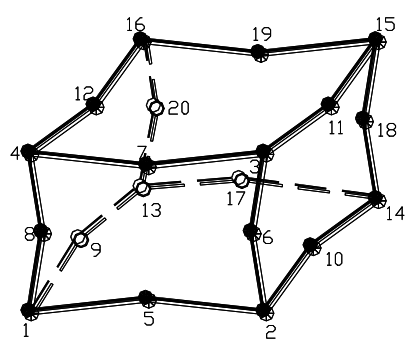

(a) IPQS Element

(Soil)

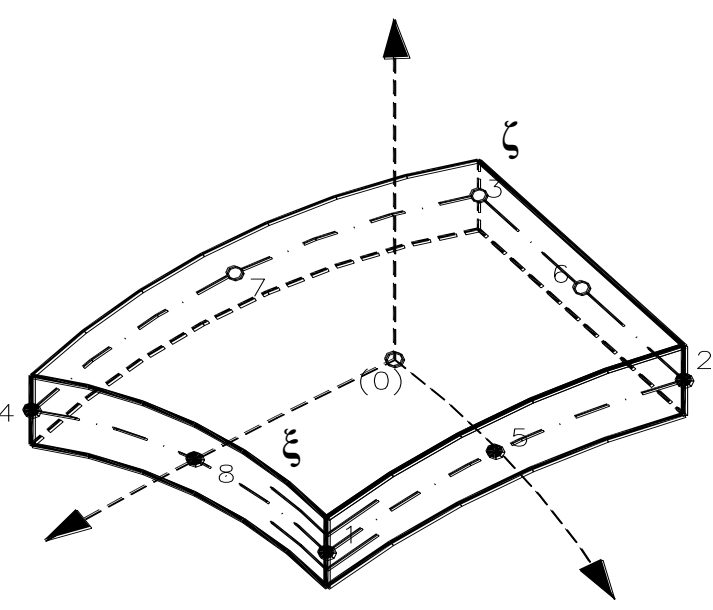

(b) ISSQ Element (Concrete Lining)

Fig. (7): The used Finite elements

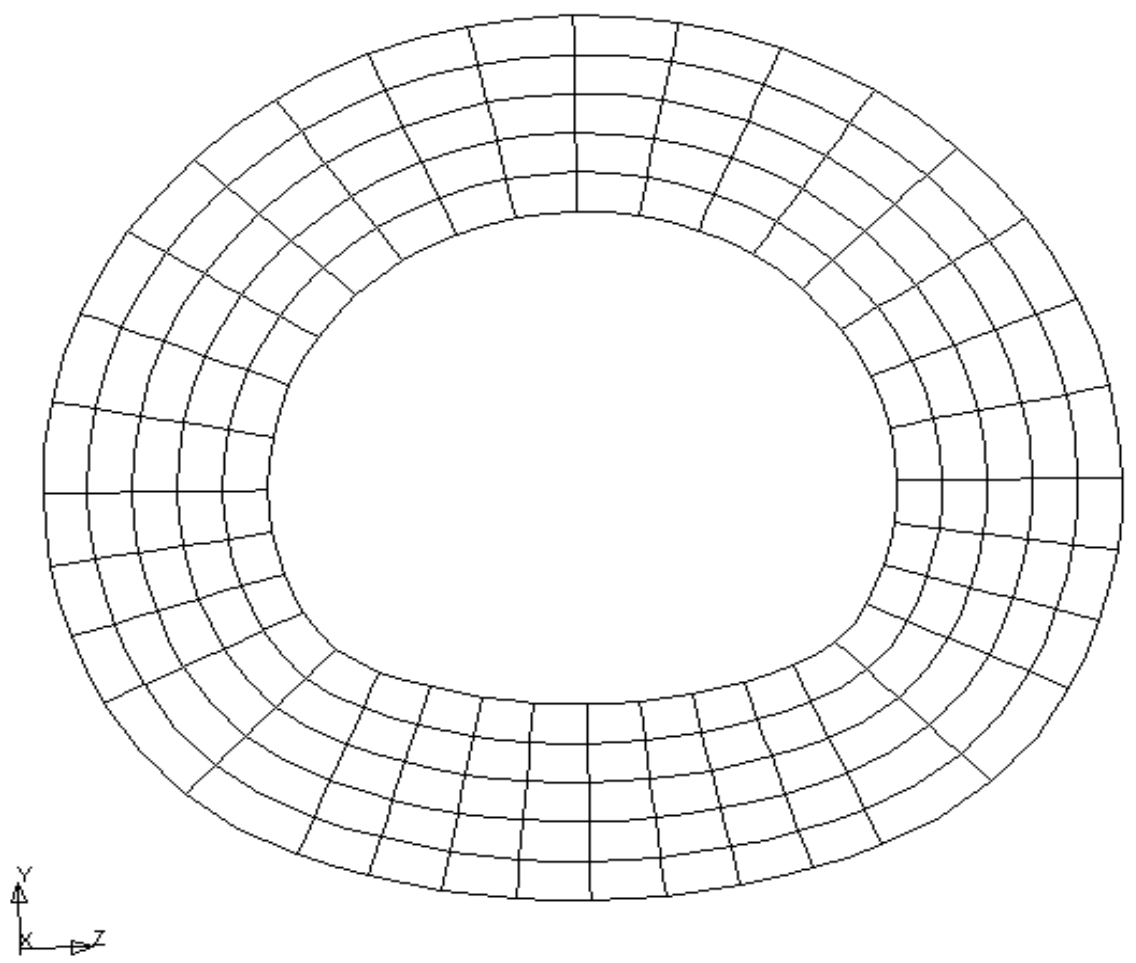

Fig. (8.a): Finite element mesh for soil (IPQS element) 


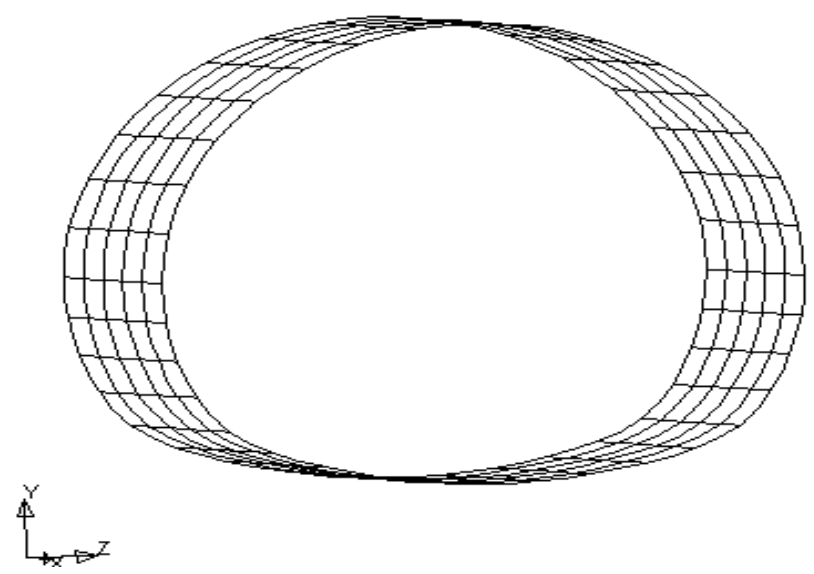

Fig. (8-b): Finite element mesh for the tunnel lining (ISSQ element)

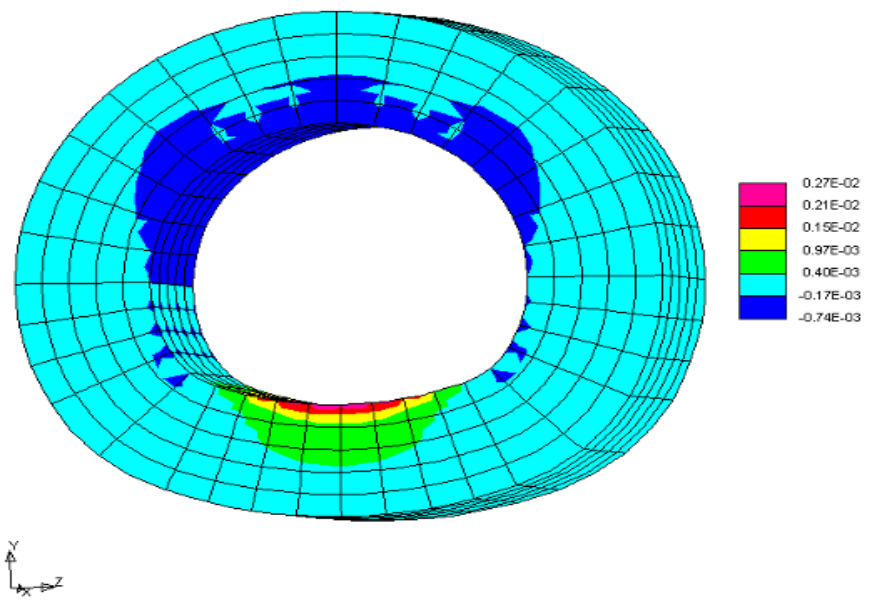

Fig. (9): Load case 1: Deformation in Y-direction [m]

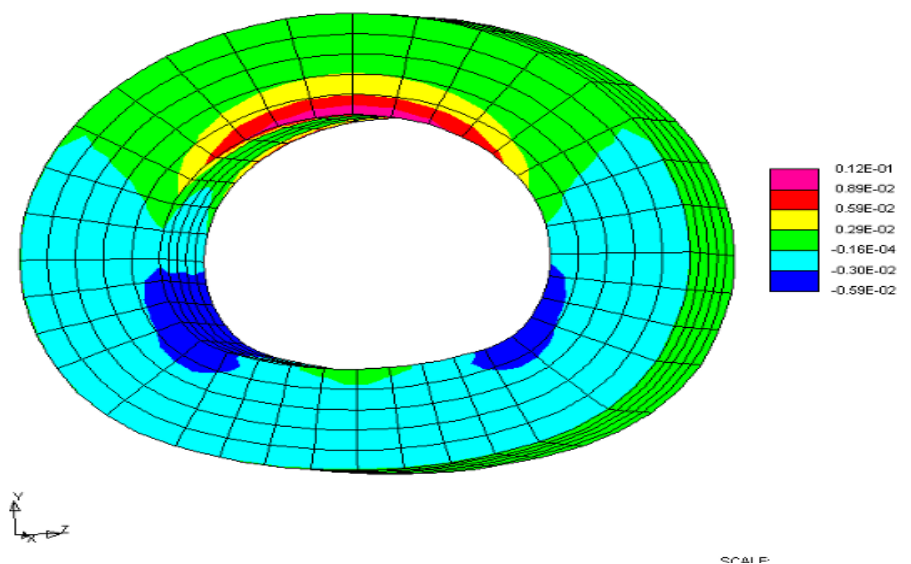

Fig. (10): Load case 2: Deformation in Y-direction 


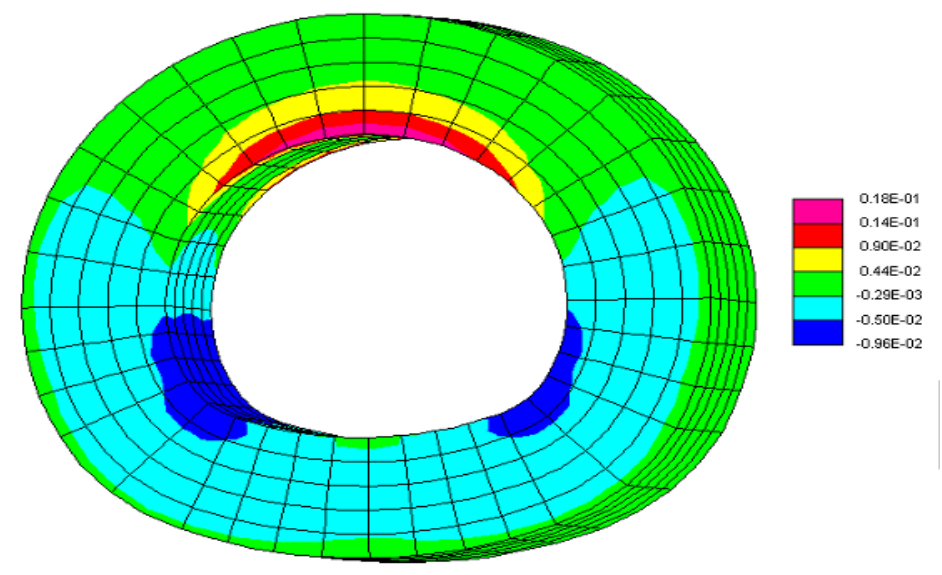

$4^{x} t^{7}$

Fig. (11): Load case 3: Deformation in Y-direction [m]

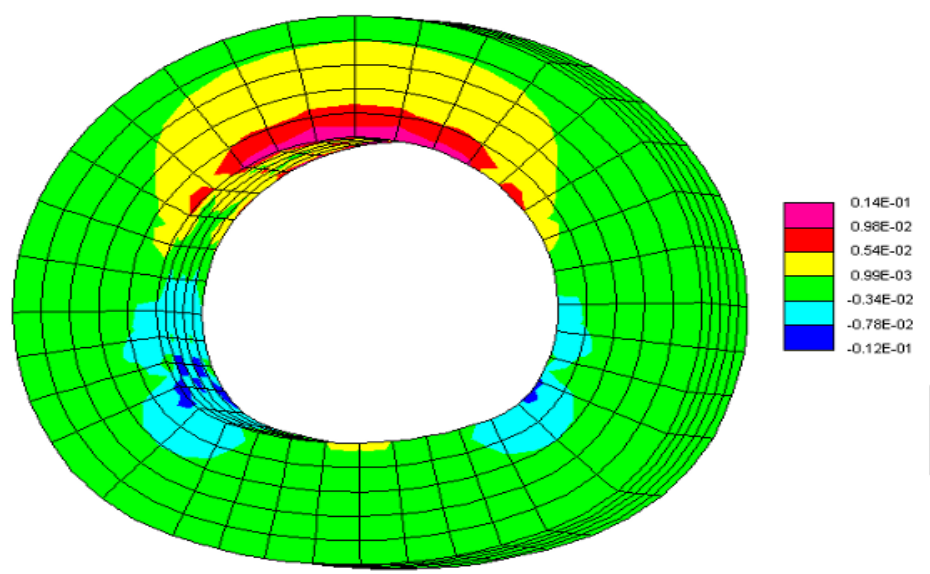

$4_{x \rightarrow 7}^{x}$

Fig. (12): Load case 4: Deformation in Y-direction [m]

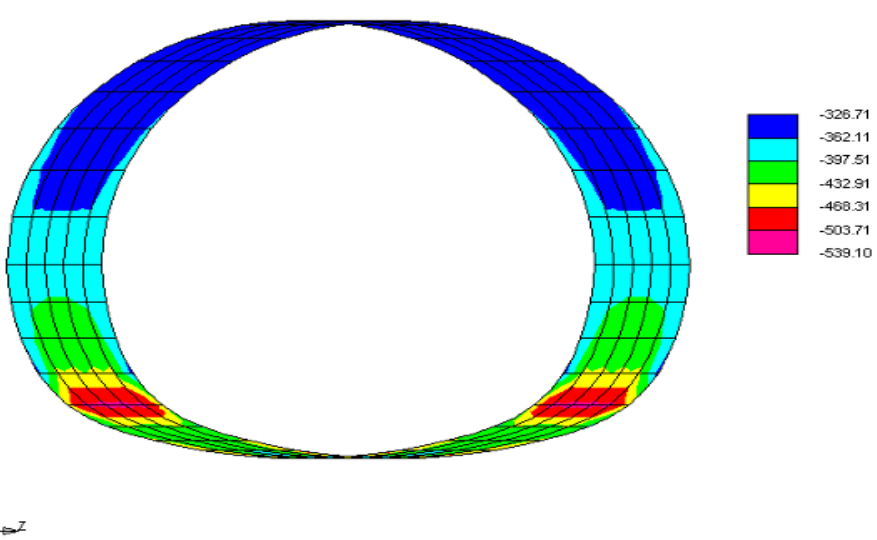

Fig. (13): Load case 1: $N_{Y}$ diagram for the shell $[k N]$ 


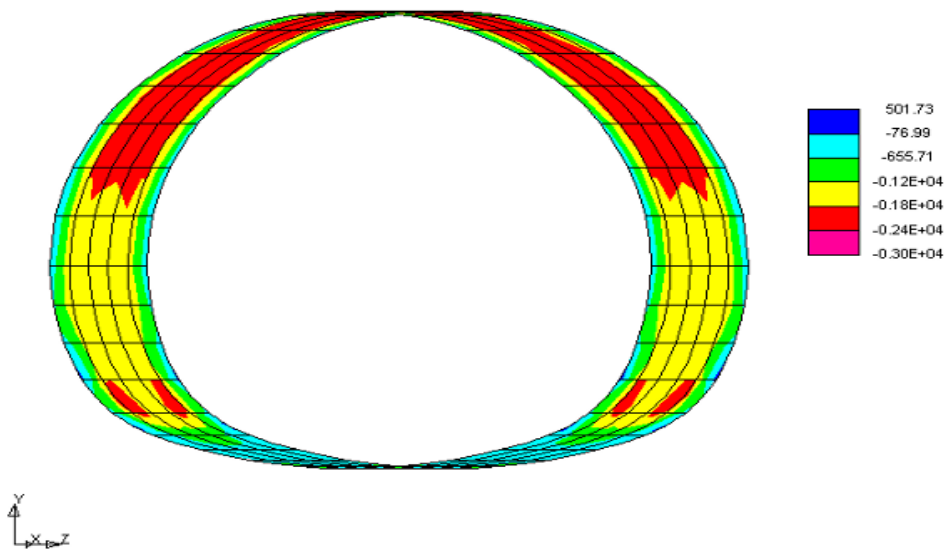

diagram for the shell $[k N]$ Fig. (14): Load case 2: $N_{V}$

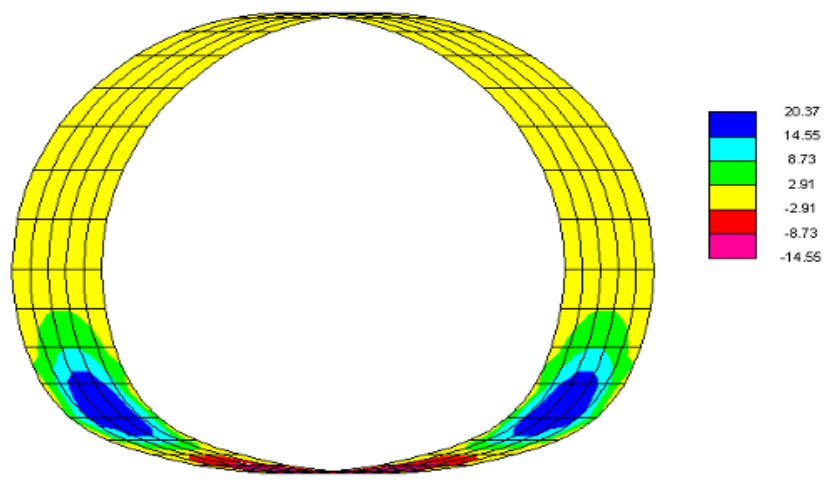

Fig. (15): Load case 1: $M_{Y}$ diagram for the shell $[\mathrm{kN} \mathrm{m} / \mathrm{m}]$

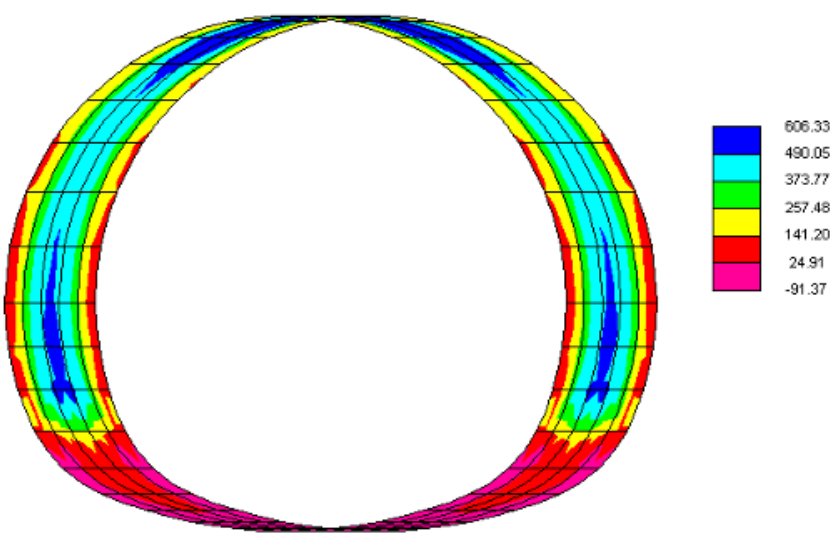

Fig. (16): Load case 2: $M_{Y}$ diagram for the shell $[\mathrm{kN} \mathrm{m} / \mathrm{m}]$ 


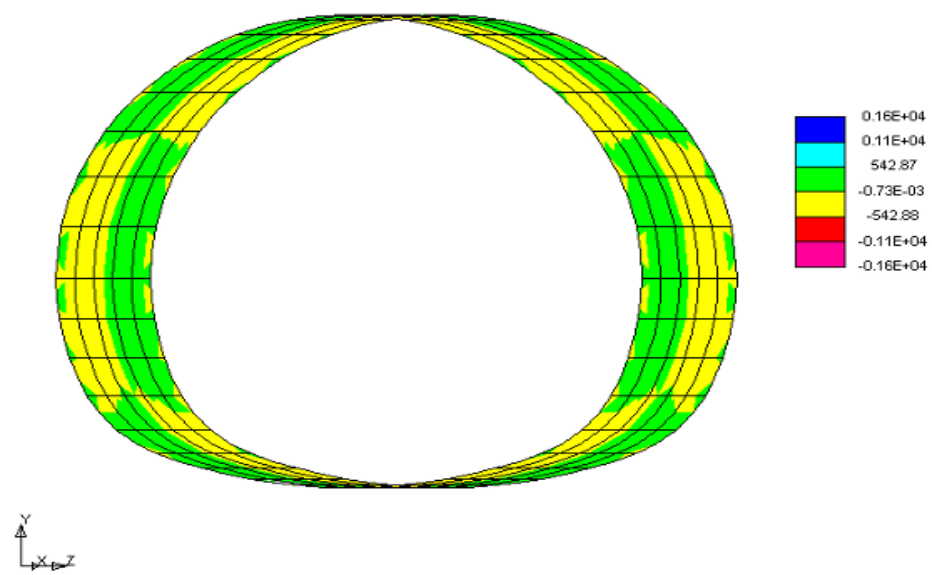

Fig. (17): Load case 1: $Q_{X Y}$ diagram for the shell $[k N]$

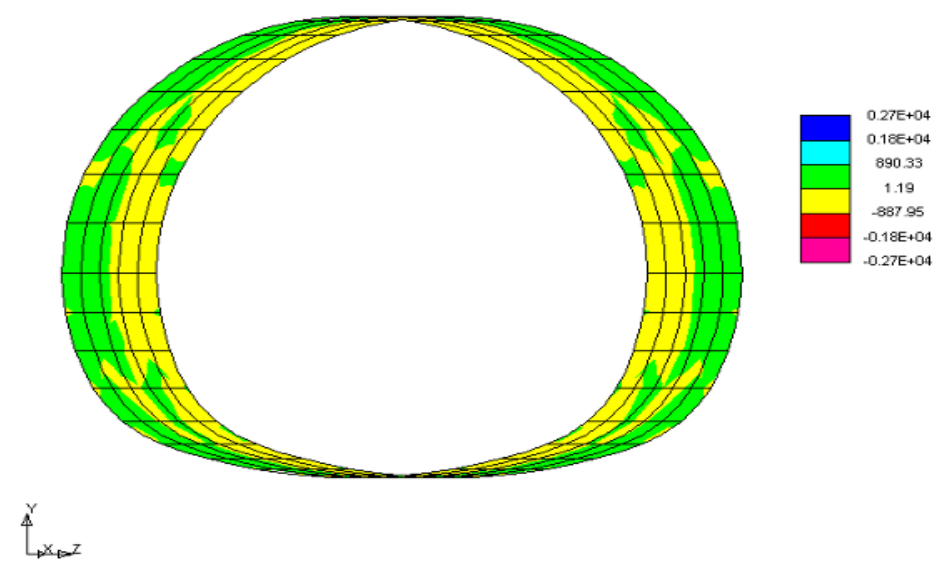

Fig. (18): Load case 3: $Q_{X Y}$ diagram for the shell [kN]

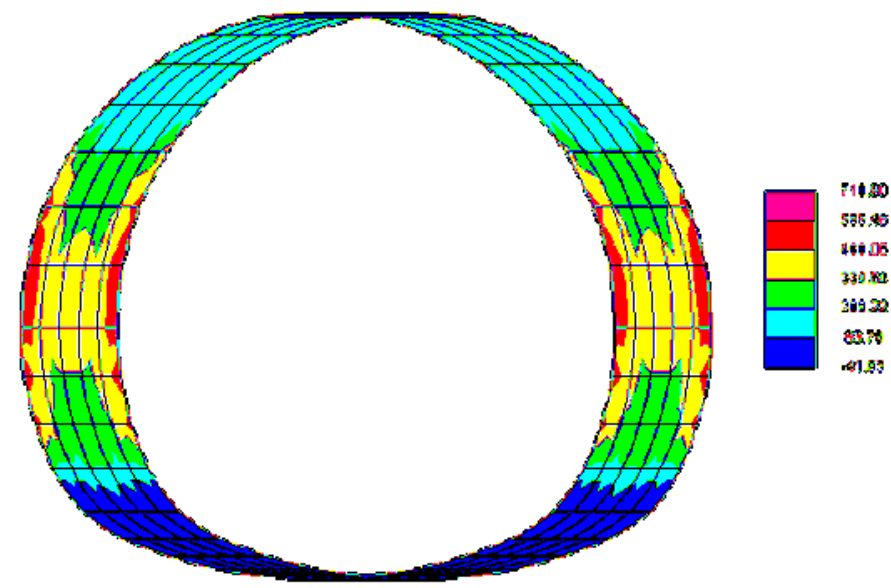

Fig. (19): Load case 2: Steel forces $N_{Y}[k N]$-external layer 


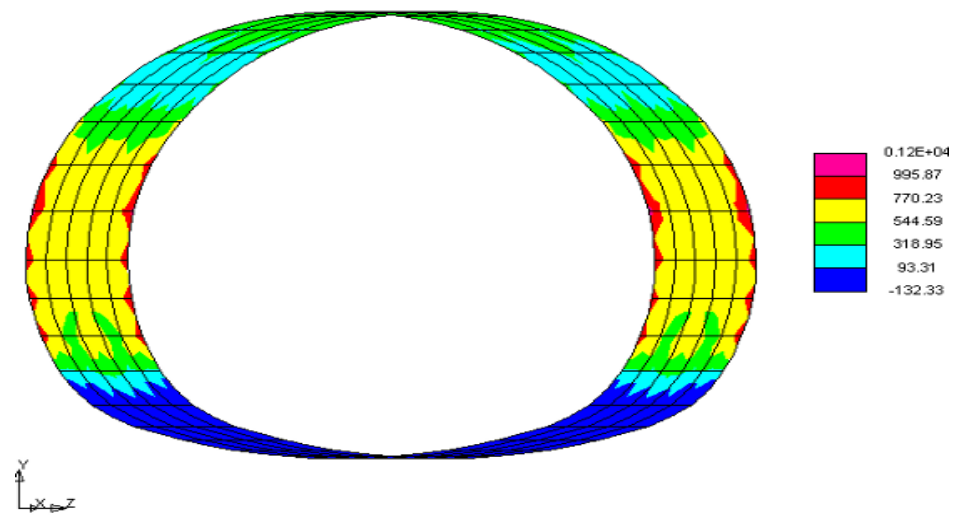

Fig. (20): Load case 3: Steel forces $N_{Y}[k N]$-external layer

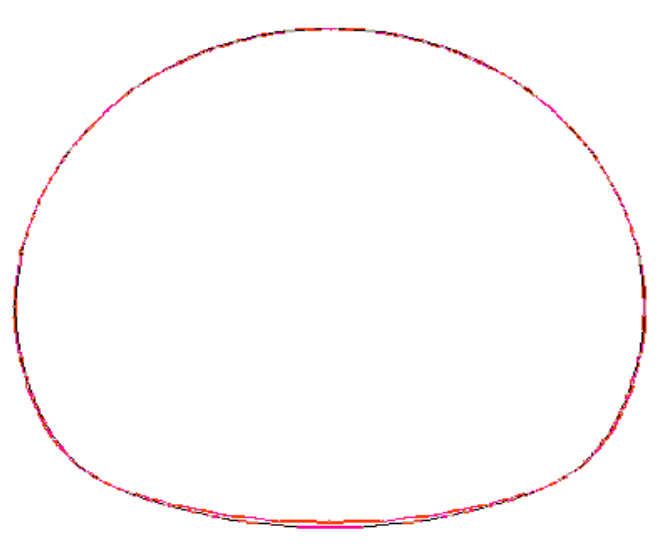

a- Load case

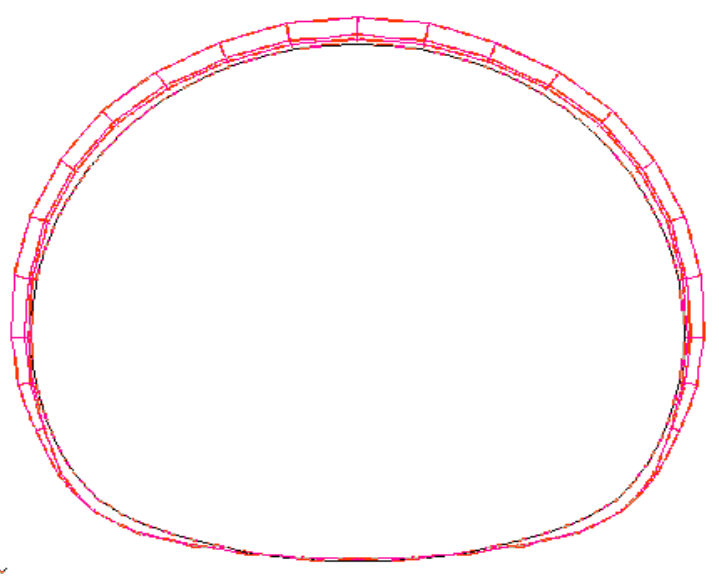

b- Load case 2

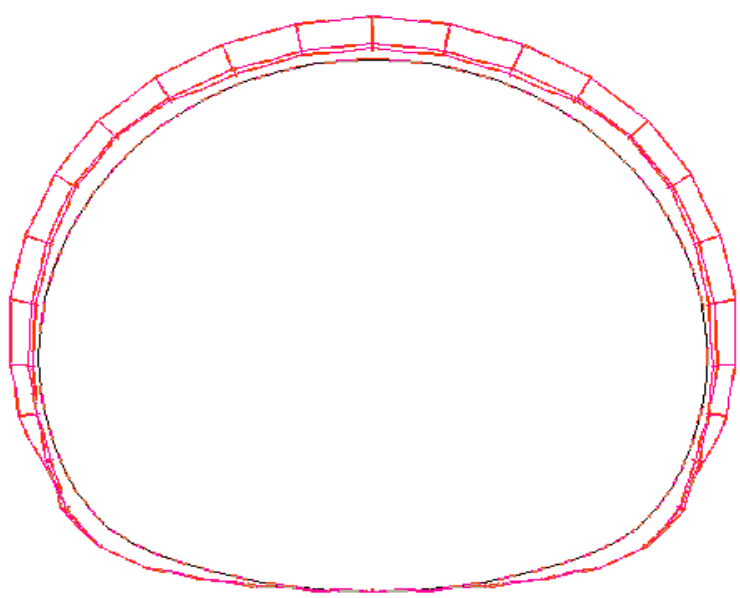

c- Load case 3

Fig. (21): Deformed and non-deformed shape of the tunnel lining (Total deformation) after different cases of loading 


\section{TWO-DIMENSIONAL MODEL}

In this case, a two-dimensional plane strain model is employed to analyze the tunnel by the program FINAL [7]. A Linear Strain Triangular element (LST) is used to model both the soil and the shotcrete tunnel lining. The materials is considered as elastoplastic materials and analyzed by Mohr-Coulomb criterion. The steel is modeled by BEAM 2 element, both concrete and soil have been presented by LST element, and the interaction between the ground soil and tunnel lining is modeled by JOINT element, as shown in Fig. (22-a) to Fig. (22-c) respectively. Fig. (23) presents the finite element mesh for this model. Different results are introduced in Figs. (24) to (26).

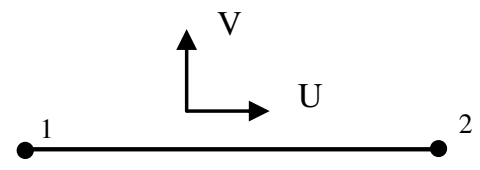

(a) BEAM 2 Element (Steel bars)
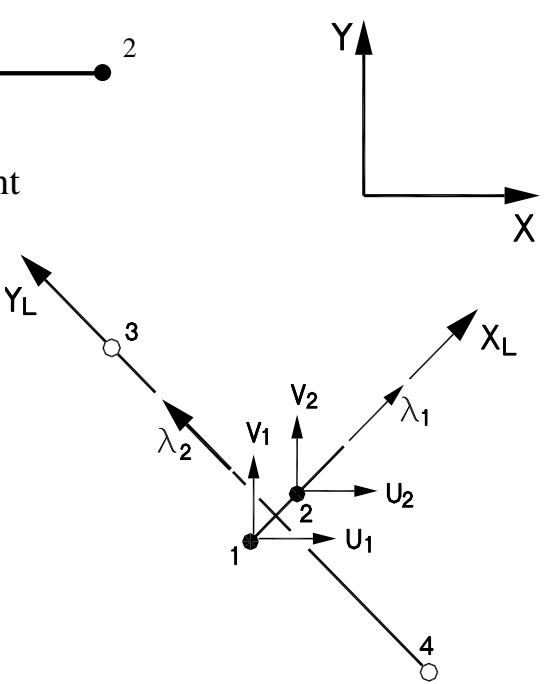

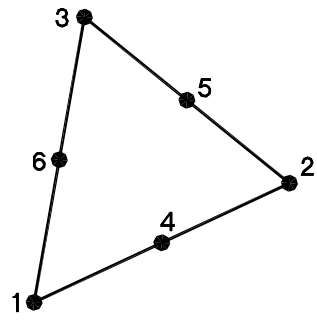

(b) LST Element

(Soil \& Concrete)

(c) JOINT Element (Interface between Soil and concrete)

Fig. (22): The used finite elements for 2-D model

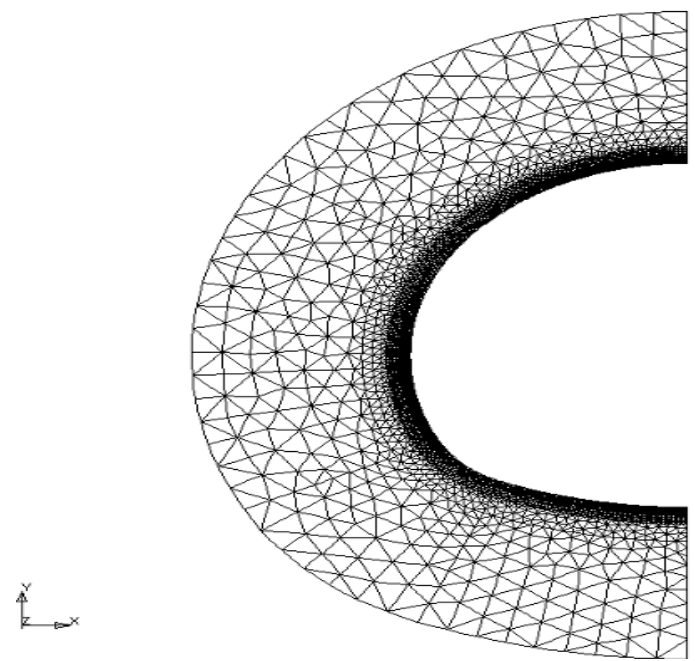

Fig. (23): The finite element mesh for 2-D model 

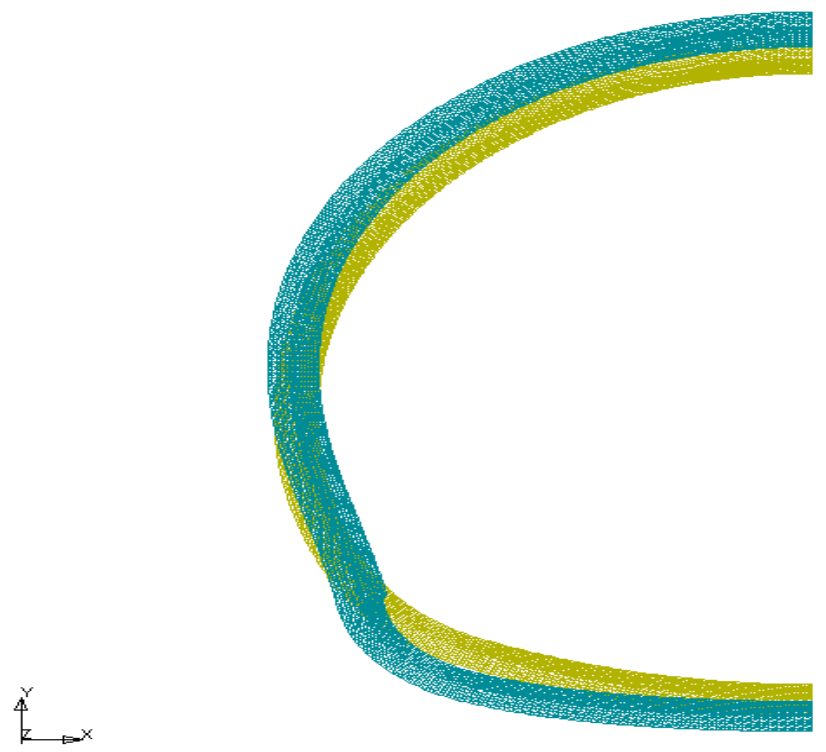

a- load case 2

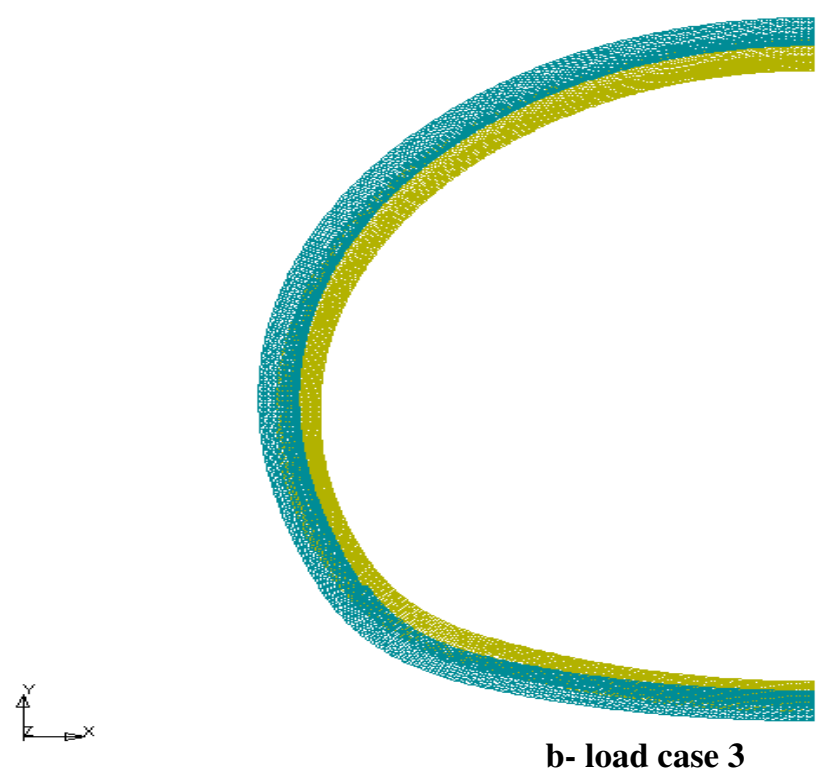

Fig. (24): Deformed and non-deformed shape of the tunnel lining 


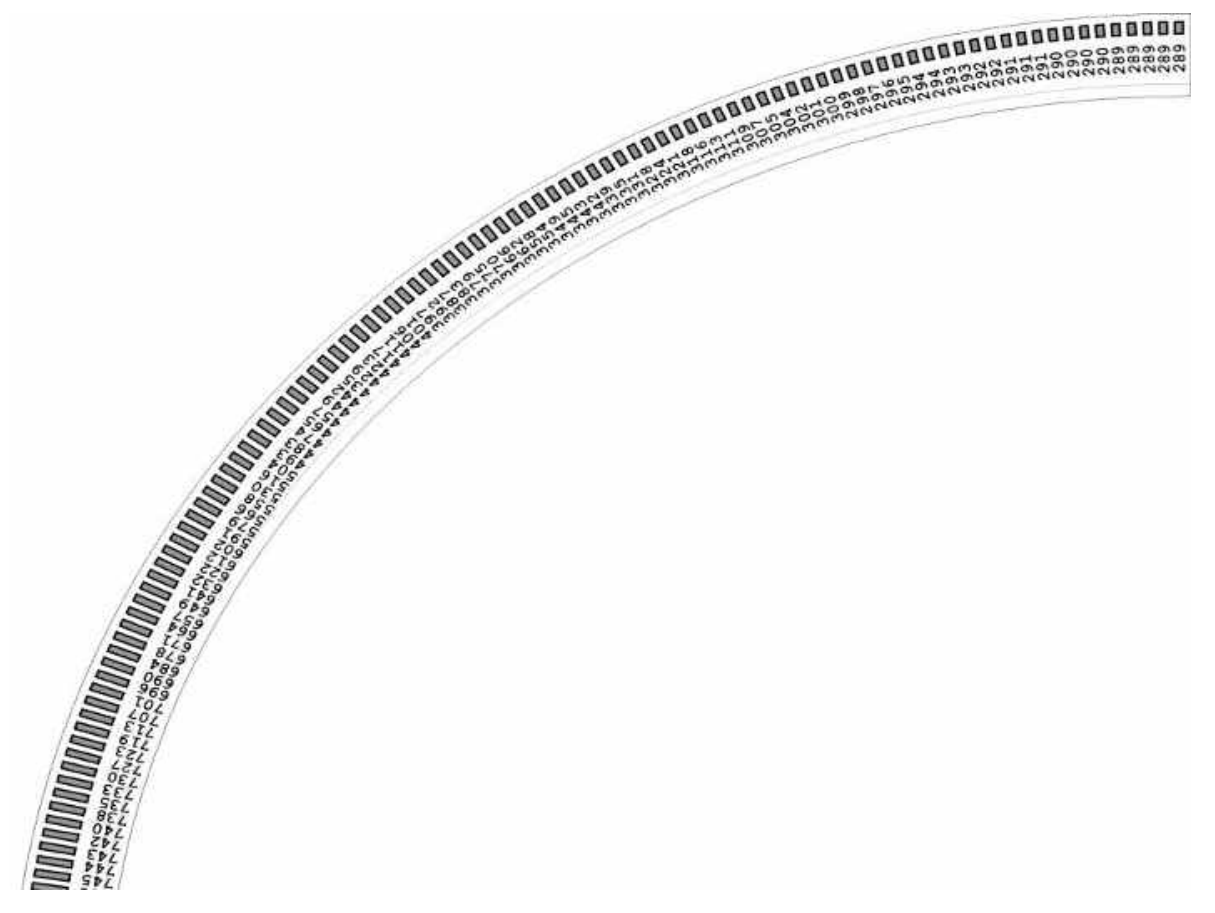

Fig. (25): Load case 2: Steel forces $N_{Y}[k N]$-external layer

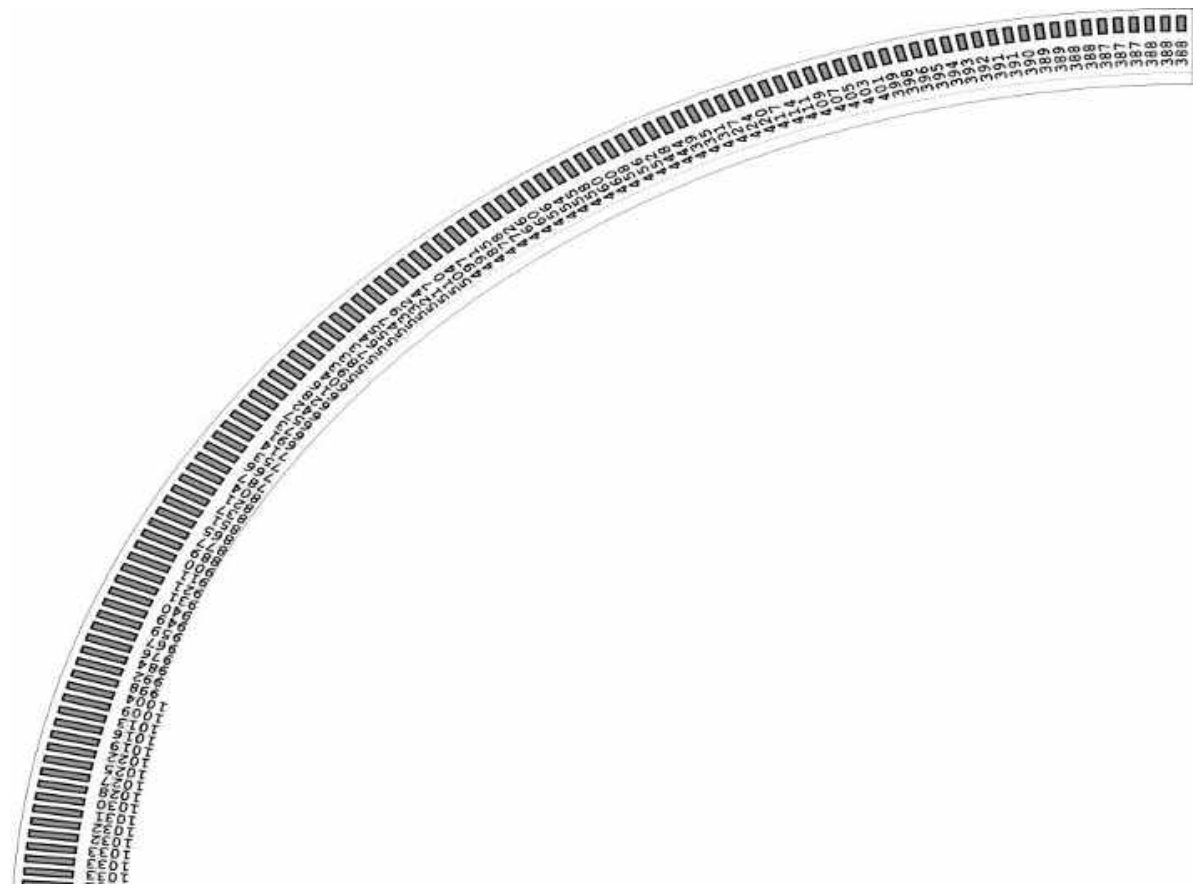

Fig. (26): Load case 3: Steel forces $N_{Y}[k N]$-external layer 


\section{RESULTS AND DISCUSSION}

As mentioned before, in the three-dimensional model, the soil was considered as an elastic material while in the two-dimensional model, it is considered as an elastoplastic material with the previously mentioned mechanical properties. During loading, the progress of the forces in concrete lining, the stresses in surrounding soil and tunnel deformations have been investigated. The results and discussion obtained from the numerical investigation performed through the three dimensional simulations are as follows:

\section{1 Soil Deformations}

The vertical deformations in the surrounding soil are illustrated in Figs. (9) to (12). At initial state, the deformation of the upper part (the part adjacent to the tunnel lining) was moved upward while the deformation of the lower part was downward. After 60 minutes fire, an increase in the deformation happened but in this case the directions were reversed, that the deformation was downward for the upper part and upward for the lower part. After 120 minutes, the directions of the deformation were as those after 60 minutes except that there was an increase in the deformation for some points. The increase reached $63 \%$ from that happened from 60 minutes case. After 240 minutes (cooling process) the deformation followed the same profile as in cases of 60 and 120 minutes, except that a significant reduction with a maximum value of about $22 \%$ occurred.

\section{2 Axial Forces in the Tunnel Lining}

The axial forces in the tunnel lining are shown in Figs. (13) and (14). It is clear from the figures that as the temperature increases, the compressive axial forces increase. After 60 minutes, the increase in the tangential direction reached $820 \%$ in the upper part in comparison with the initial state. This phenomenon can be happened because of two reasons, as follows:

The first reason is that, when the temperature was increased, thermal strains and consequently thermal stresses were emerged in the tunnel lining. These thermal strains and stresses depend mainly on the temperature, that higher temperature causes higher thermal stresses and strains. Because the axial forces are typically related to the stresses, an increase in the axial forces happened.

The second reason is that, by increasing the temperature, a dramatic decrease in the load bearing capacity and modulus of elasticity occurred. This decrease depends on the distance of the studied concrete element from the fired face (in our case, the internal side of the tunnel lining). This decrease reached its maximum values for the internal layers that for example after 120 minutes fire loading, the first and second layer totally destroyed. This means that the effective thickness in the cross section of the tunnel lining will decrease. Decreasing in the effective thickness that will redistribute the stresses to the undamaged areas and will be carried by smaller bearing area and that will increase the applied stresses and strains and consequently higher axial forces are obtained. 


\section{3 Bending Moments and Shearing Forces in the Tunnel Lining}

The bending moment and shearing force diagrams developed in the tunnel lining during different loading cases are shown in Figs. (15) to (18). In general, an increase and redistribution on the bending moments and shearing forces can be observed. This is also due to the high stresses which emerged because of the high temperature and due to the decrease in the thickness of the tunnel lining.

\section{4 Comparison with 2-D Model Results}

Similar results have been obtained using two-dimensional model in comparison with the three-dimensional calculations. The profile of stresses, deformations and forces were approximately the same and the observed difference in the values was because of the difference in accuracy, the different used criteria and types of used finite elements in both models.

Figure (21) shows the deformed and non-deformed shape of the tunnel lining at initial state, after 60 and 120 minutes when calculated by the three-dimensional model while Fig. (24) shows the deformed and non-deformed shape of the tunnel lining after 60 and 120 minutes for the two dimensional calculations. By comparison, a big similarity can be observed for the progress of the deformation after 60 and 120 minutes fire loadings.

The results of the axial forces in the external steel layer (layer No. 20) in threedimensional model are indicated in Figs. (19) and (20) while for two dimensional calculations, they are illustrated in Figs. (25) and (26) for the two fire loadings (60 and 120 minutes). Therefore, it can be noticed from the figures that the profile of the forces is approximately the same after 60 minutes fire loading. The difference in the maximum values after 60 minutes fire loading was about $5.2 \%$ while the difference in the maximum values reached about $14 \%$ after 120 minutes fire loading. This comparison is illustrated in Table (5).

Table (5): Comparison between 2-D and 3-D models results

\begin{tabular}{|c|c|c|c|}
\hline \multirow[t]{2}{*}{ Loading No. } & \multicolumn{2}{|c|}{ Maximum steel force } & \multirow[t]{2}{*}{ Difference $\%$} \\
\hline & 2-D model & 3-D model & \\
\hline Load case 2 & 748 & 710.9 & 5.2 \\
\hline Load case 3 & 1033 & 1200 & 14 \\
\hline
\end{tabular}

\section{CONCLUSIONS}

- A numerical analysis was carried out for a tunnel subjected to fire by a 3-D plastic model using finite element method. The model adopted the most sophisticated yield criterion of Willam-Warnke five-parameter model.

- The tunnel was analyzed during heating and cooling processes and compared with a 2-D Mohr-coulomb plasticity calculation for the same tunnel during both heating and cooling processes. 
- The stresses, deformations and the loads during heating and cooling processes were described reasonably by the 3-D model and a very good agreement is found between the results of the two and three-dimensional model calculations.

- The analysis showed that the fire has a severe destructive impact on concrete lining. The emerged stresses due to high temperature are always accompanied by reducing in the loading capacity, in the effective area of the material that a total damage may be occurred for some parts of the material which subjected to high temperature. So, a great attention must be taken into consideration when designing structures subjected to fire.

\section{REFERENCES}

1. Kordina K. and Meyer-Ottens C.,: "Beton Brandschutz Handbuch", Beton-Verlag GmbH, Düsseldorf (1981).

2. Chan Y. N., Peng G. F. and Anson M.: "Residual strength and pore structure of high-strength concrete and normal strength concrete after exposure to high temperature", Cement and Concrete Composites, 21, 23-27 (1999).

3. Malhotra H. L.,: "The effect of temperature on the compressive strength of concrete", Magazine of Concrete Research, 18, no 23, 85-94 (1956).

4. Zha X. X.,: "Three-dimensional nonlinear analysis of reinforced concrete members in fire", Building and Environment, 38, 297-307 (2003).

5. Pren 1992-1-2: "Eurocode 2, Bemessung und Konstruktion Von Stahlbeton-und Spannbetontragwerken, Teil 1-2: Allgemeine Regeln-Tragwerksbemessung für den Brandfall. Europäisches Komitee fürNormung, 2003

6. Kusterle W., Lindlbauer W. et al.: "Brandbeständigkeit von Faser-, Stahl- und Spannbeton", Straßenforschungsauftrag Nr. 3.269 des Bundesministeriums für Verkehr, Innovation und Technologie und auftrag der Eisenbahn Hochleistungsstrecken AG, Wien (2004)

7. Swoboda, G.,: "Program system FINAL- Finite element analyses program for linear and nonlinear structure"s, Version 7.1, (2001).

8. Han D. J. and W. Chen, "A Nonuniform hardening plasticity model for concrete materials". Mechanics of Materials, 4, 283-302 (1985).

9. Chen W F. and Suzuki H.,: "Constitutive models for concrete", computer and Structures, 12, 23-32 (1980).

10. Chen, A. C. T. and Chen, W. F.,: "Constitutive relations for concrete", Journal of the Engineering Mechanics Division, 101, 465-481 (1975).

11. Khaled A. M., Yehia A. H. and Abd EL Rahman M. A.,: "Numerical Modelling of 3-D Concrete Structures by finite element method", December (2004), Cairo, Egypt.

12. Khaled A. M., Yehia A. H. and Abd EL Rahman M. A.,: "Analysis of Concrete Shell Structures Subjected to High Temperature by Using Layered Element". JES, Faculty of Engineering Assiut University July, (2005)

13. Ziegler H.,: "Modification of Prager's hardening rule" andJournal of Applied Mechanics, 17, 55-65 (1959).

14. COMITE EURO-INTERNATIONAL DU BETON (CEB), "Fire design of concrete structure", CEB, Lausanne, July (1991). 
15. Swoboda, G.,: "Numerical modelling of tunnels", Numerical Methods and Constitutive Modelling in Geomechanics. Springer-Verlag, Wien (1990).

16. Willam K. J. and Wranke E. P.,: "Constitutive model for the triaxial behaviour of concrete". International Association for Bridge and Structural Engineering proceedings, 19, 1975.

\section{التحليل النظري لبطانة الأنفاق المعرضة للحريق}

\section{محمود حني منصور}

في السنوات الأخيرة وقعت كثثر من الحوادث المدمرة في الأنفاق بسبب الحرائق والتي تزداد خطورتها بزيادة كثافة المرور • ويزداد تأثير الحرائق على الخرسانة المبطنة للأنفاق والتي عادة ما تكون

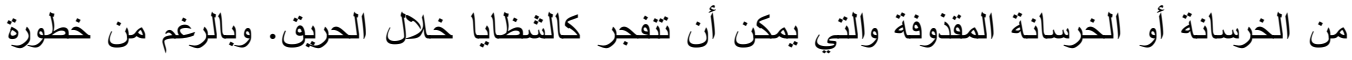

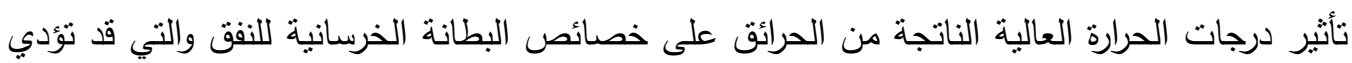
إلى انهيارها، إلا أن معظم الأبحاث السابقة كانت تركز على المنشآت الخرسانية التقليدية دون التركيز على الأنفاق. ونظرا لأهمية الأنفاق الاقتصادية والسياسية فإنه من المهم معرفة كيف ومنى ينم إعادة

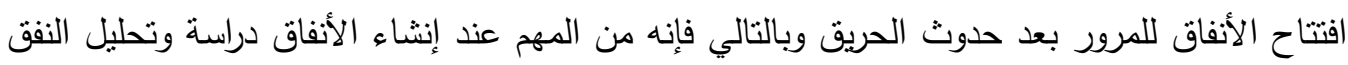
تحت درجات الحرارة العالية باستخدام نماذج رياضية تمثل بطانة النفق والتربة المحيطة به. الغرض الرئيسي من هذا البحث هو عمل نموذج دقيق لدراسة الخواص الميكانيكية للخرسانة

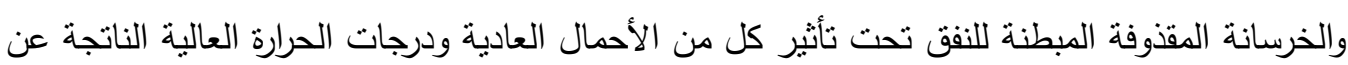

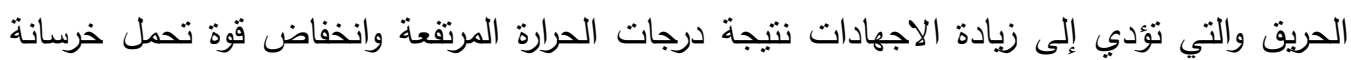
بطانة النفق نتيجة لتغير الخواص الميكانيكية والكيميائية للخرسانة أثثاء وقوع الحريق وأثناء التبريد الناتج عن عملية الإطفاء. وقد نم عمل تحليل عددي لنفق باستخدام نموذج ثلاثي الأبعاد باستخدام نظرية العناصر المحدودة بناء على نظرية اللدونة باستخدام النموذج المعروف -Willam-Warnke five)

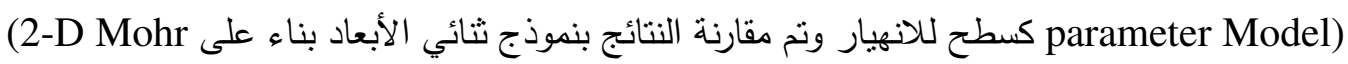
كلا Coulomb plasticity) كلا النموذجين. كما أوضحت الدراسة أن الحريق له تأثير مدمر على بطانة النفق وأن الاجهادات الناتجة

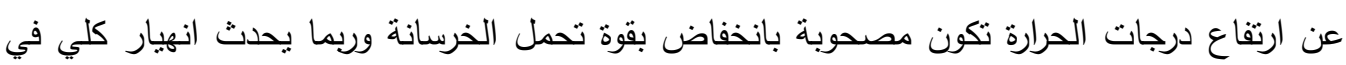
بعض الأجزاء المعرضة للحرارة ولذلك يجب أخذ ذلك في الاعتبار عند تصميم المنشآت الخرسانية المعرضة للحريق. 